\title{
Unexpectedly fast catalytic transfer hydrogenation of aldehydes by formate in 2-propanol-water mixtures under mild conditions
}

\author{
Imre Szatmári ${ }^{\mathrm{a}}$, Gábor Papp ${ }^{\mathrm{b}}$, Ferenc Joó ${ }^{\mathrm{a}, \mathrm{b}, *}$, Ágnes Kathóo ${ }^{\mathrm{a}, 1}$ \\ a University of Debrecen, Department of Physical Chemistry, P.O. Box 7, H-4010 Debrecen 10, Hungary \\ ${ }^{\mathrm{b}}$ MTA-DE Homogeneous Catalysis and Reaction Mechanisms Research Group, P.O. Box 7, H-4010 Debrecen 10, Hungary
}

\section{A R T I C L E I N F O}

Article history:

Received 16 April 2014

Received in revised form 24 May 2014

Accepted 18 June 2014

Available online $\mathrm{xxx}$

\section{Keywords:}

Unsaturated aldehyde

Transfer hydrogenation

Ruthenium-phosphine catalyst

Sodium formate

Water

2-Propanol

\begin{abstract}
A B S T R A C T
Unsaturated aldehydes were efficiently reduced by transfer hydrogenation from sodium formate in water-2-propanol mixtures using a water-soluble $\mathrm{Ru}(\mathrm{II})$-tertiary phosphine catalyst. The reaction yielded unsaturated alcohols with complete selectivity and without hydrogenation or isomerization of $\mathrm{C}=\mathrm{C}$ bonds of the substrates. Very high reaction rate was observed in the transfer hydrogenation of cinnamaldehyde already at $30^{\circ} \mathrm{C}$ with turnover frequency of $160 \mathrm{~h}^{-1}$ and this increased to $3800 \mathrm{~h}^{-1}$ at $70{ }^{\circ} \mathrm{C}$. Consequently, the method is applicable to the synthesis of unsaturated alcohols in case of heat sensitive or highly volatile aldehydes, too. Based on multinuclear NMR investigations, trans-[ $\left.\mathrm{RuH}_{2}\left(\mathrm{H}_{2} \mathrm{O}\right)(m \mathrm{tppms})_{3}\right]$ is suggested as the key catalytic species.
\end{abstract}

(c) 2014 Elsevier B.V. All rights reserved.

\section{Introduction}

Hydrogenation of aldehydes is a synthetically important reaction and has attracted much interest both from the heterogeneous and homogeneous catalysis community. Selective hydrogenation of $\alpha, \beta$-unsaturated aldehydes is a particularly challenging problem because the reaction may yield three products all of which have their important applications as starting materials for flavor and fragrance substances. A specific example (Scheme 1 ) is the reduction of cinnamaldehyde (trans-3-phenyl-2-propenal, A) which supplies cinnamyl alcohol (3-phenyl-2-propenol, B), 3-phenyl-propanal (C) and 3-phenyl-propanol (D).

Several homogeneous catalytic hydrogenation processes were reported in the literature for the reduction of aldehydes [1-30], however, in most cases catalyst recovery and product isolation were cumbersome. Limited solubility of aldehydes in water allows the use of aqueous-organic biphasic systems with the use of water-soluble catalysts. In such systems, the catalyst resides in the aqueous phase while the substrate is found in the organic phase so they can be separated upon completion of the reaction. Most often the water-soluble catalysts contain sulfonated phosphine ligands

\footnotetext{
* Corresponding author at: University of Debrecen, Department of Physical Chemistry, P.O. Box 7, H-4010 Debrecen 10, Hungary. Tel.: +36 52 512900x22382.

E-mail addresses: joo.ferenc@science.unideb.hu, joofer49@yahoo.com (F. Joó).

1 Author for further information.
}

such as $m$ tppms (sodium 3-diphenylphosphinobenzenesulfonate) [31], mtppts (trisodium 3,3',3"'-phosphinetriylbenzensulfonate) [32] or pta (1,3,5-triaza-7-phosphatricyclo[3.3.1.1]decane or 1,3,5-triaza-7-phosphaadamantane) [33]. Typical catalysts are $\left[\left\{\mathrm{RuCl}_{2}(m \mathrm{tppms})_{2}\right\}_{2}\right]$ [7], $\left[\mathrm{RhCl}(m \mathrm{tppts})_{3}\right]$ [7] or the in situ prepared $\mathrm{Rh}(\mathrm{I})$-complexes with water-soluble thioligands, such as (L)-cysteine or (s)-captopril [20]. Hydrogenation of allylic alcohols may proceed via isomerization to aldehydes or ketones and in such cases the catalyst should be able to facilitate the hydrogenation of the $\mathrm{C}=\mathrm{O}$ function [34-36]. In general, it can be stated that the rhodium(I)-based catalysts are more active in hydrogenation of the $\mathrm{C}=\mathrm{C}$ bond, while the $\mathrm{Ru}(\mathrm{II})$-complexes prefer hydrogenation of the $\mathrm{C}=\mathrm{O}$ bond. Nevertheless, this can be regarded only as a vague rule of orientation because the actual selectivity may depend on many factors such as, e.g. the $\mathrm{pH}$ of the aqueous phase or the hydrogen pressure. Hydrogenation of aldehydes in aqueous-organic biphasic systems has been reviewed recently [4].

Transfer hydrogenation is a highly efficient and versatile tool for reducing various unsaturated compounds. Although several hydrogen donors have been found useful for this purpose, the two most extensively investigated are 2-propanol and formic acid/formate salts. In most cases, 2-propanol is used in the presence of a strong base ( $t-\mathrm{BuOH}, \mathrm{KOH}$, etc.) very often applying $\mathrm{Ru}(\mathrm{II})$-based homogeneous catalysts. Excellent rates and selectivities were achieved by Noyori [37], Bäckvall [8], Xiao [38] and others in synthesis of secondary alcohols. In general, water is not well tolerated in such processes [38], and several studies showed that both the rates and 


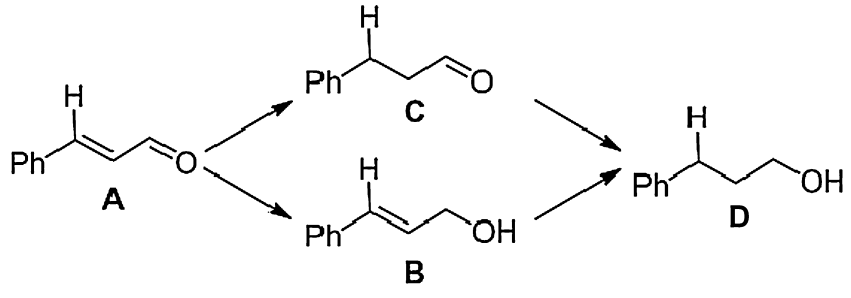

Scheme 1. Hydrogenation of trans-cinnamaldehyde.

selectivities decrease substantially with increasing water content of the 2-propanol-water mixtures even in those cases when watersoluble catalysts were applied. Notable exceptions are the transfer hydrogenations of ketones studied by Williams et al. $[39,40]$ and by Ajjou and Pinet [11] where up to $51 \%$ (v/v) water could be applied beneficially. Xiao applied a water-insoluble catalyst in aqueous-organic biphasic system for transfer hydrogenation of ketones from formate and observed an accelerating effect of water (on water reaction) [41].

In contrast to 2-propanol, the most suitable solvent for formic acid/formate salts is water and the insolubility of many of the aldehyde or ketone substrates in water allows to run transfer hydrogenations in aqueous-organic biphasic systems. Both aldehydes and ketones were successfully hydrogenated by H-transfer from aqueous formate using $\mathrm{Ru}(\mathrm{II})$-complexes as catalysts [42-47]. $\mathrm{Rh}(\mathrm{I})$ - and $\operatorname{Ir}(\mathrm{I})$-complexes are also known to act as catalysts in such reactions [48,49], in fact, $\operatorname{Ir}(\mathrm{I})$-complexes with monotosylated ethylenediamine ligands $[9,10]$ showed outstanding catalytic activities up to turnover frequencies, TOF $=3.0 \times 10^{5} \mathrm{~h}^{-1}(\mathrm{TOF}=\mathrm{mol}$ reacted aldehyde $\left.\times(\text { mol catalyst })^{-1} \times \mathrm{h}^{-1}\right)[10]$.

Interestingly, in the first biphasic transfer hydrogenation of aldehydes both the $\left[\mathrm{RuCl}_{2}\left(\mathrm{PPh}_{3}\right)_{3}\right]$ catalyst and the substrates were dissolved in the same (organic) phase and the aqueous phase served only as a reservoir of the $\mathrm{H}$-donor (Na-formate) [42,43]. Consequently, a phase transfer catalyst (Aliquat 336) had to be used in order to attain reasonably high reaction rates. In addition, due to substrate inhibition [42], the aldehyde concentration in the organic phase had to be kept low. For substrate-catalyst separation and catalyst recycling a better arrangement is to dissolve the catalyst together with HCOONa in the aqueous phase and contact it with an organic phase of the aldehyde (neat or dissolved in a suitable solvent, such as, e.g. toluene). In such an aqueous-organic biphasic system, we achieved $100 \%$ selective transfer hydrogenation of unsaturated aldehydes to unsaturated alcohols at $80^{\circ} \mathrm{C}$ by using $\left[\left\{\mathrm{RuCl}_{2}(m \text { tppms })_{2}\right\}_{2}\right]+n m$ tppms or $\left[\mathrm{RuCl}_{2}(\mathrm{pta})_{4}\right]$ catalysts and $5 \mathrm{M}$ aq. HCOONa as H-donor [44-47].

Catalytic hydrogenations and transfer hydrogenations in aqueous-organic biphasic systems can be influenced by several factors which may be belong to one of the following groups: (1) effects connected to the presence of water, (2) effects of phase transfer and solubilities. Water may influence the actual molecular form of the catalyst by promoting hydrolysis (formation of hydroxocomplexes) [50]; preferring heterolytic activation of $\mathrm{H}_{2}$ [50]; allowing formation of several hydrido- and molecular hydrogen complexes from the same catalyst precursor depending on the $\mathrm{pH}$ of the aqueous phase and on $\mathrm{H}_{2}$ pressure [23,24,50]; protonation/deprotonation equilibria, etc. Concerning phase transfer and solubility effects the chemical reaction may proceed either in the catalyst-containing bulk aqueous phase, or at the interphase of the two bulk phases. The most important factor is perhaps the transfer of substrates to the interphase and their dissolution into the aqueous phase and this can limit the overall rate of the hydrogenation process. Another rate-decreasing factor is the lower solubility of $\mathrm{H}_{2}$ in water, compared to the usual organic solvents. On the other hand, limited solubility of the substrate (e.g. an aldehyde) in the aqueous phase may eliminate substrate inhibition even in cases when the aldehyde concentration in the organic phase is high (or when the neat substrate is applied without any added organic solvent) [45]. Solubility of inorganic salts in the aqueous phase can be beneficial, too. For example, significant rate increasing effects of various cations were observed in aqueous-organic biphasic hydrogenation of aldehydes with several Ru(II)-mtppts catalysts [25,26]. Finally, mutual solubility of water in the organic phase and vice versa should also be considered.

In case of substrates with very low aqueous solubility a straightforward way to speed up the reaction is the use of co-solvents. Nevertheless, a co-solvent can always increase leaching of the water-soluble catalyst into the organic phase. For example, Monflier et al. investigated the hydrogenation of water-insoluble aldehydes in the presence of various co-solvents (with $\mathrm{Ru}(\mathrm{II}$ )$m$ tppts catalysts) with beneficial effects on the reaction rate, however, the amount of co-solvents had to be kept below 5\% $(\mathrm{w} / \mathrm{w})$ of the aqueous phase due to increased leaching [51]. In other cases, the reaction was found faster in the co-solvent alone than in the water-aldehyde-co-solvent mixtures. For example, Paganelli et al. found that hydrogenation of unsaturated aldehydes such as cinnamaldehyde and 3-(1,3-benzodioxol-5-yil)-2-methylpropenal (the saturated aldehyde is the precursor of the fragrance Helional ${ }^{\circledR}$ ) was accelerated by addition of ethylene glycol to the mixture of the aldehyde and water [20]. Furthermore, the highest rate was observed by running the reaction in ethylene glycol (in what the $\mathrm{Rh}(\mathrm{I})-(\mathrm{L})$-cysteine or $\mathrm{Rh}(\mathrm{I})$-(s)-captopril were soluble under conditions of the reaction).

Similarly, Ajjou and Pinet investigated transfer hydrogenation of aldehydes (and ketones) in water/2-propanol 10/3 (v/v) mixtures with $\mathrm{Na}_{2} \mathrm{CO}_{3}$ as base and $\left[\{\mathrm{RhCl}(\mathrm{COD})\}_{2}\right]+15 \mathrm{mtppts}$ catalyst. High conversions were obtained in $2 \mathrm{~h}$ at $80^{\circ} \mathrm{C}$ (e.g. benzaldehyde 98\%, 2-thiophenecarboxaldehyde 72\%) [11]. Obviously, in this system 2-propanol had the dual role of H-donor and cosolvent. Under the applied conditions, the reaction mixtures were homogeneous and the product was isolated by extraction with diethyl ether. No unsaturated aldehydes were studied therefore no data are available from this work on the selectivity of the catalyst in basic aqueous 2-propanol.

In our earlier investigations, we have already used HCOONa as base in transfer hydrogenation of unsaturated aldehydes and ketones from 2-propanol catalyzed by chiral $\mathrm{Rh}(\mathrm{I})-, \mathrm{Ru}(\mathrm{II})$ and $\operatorname{Ir}(\mathrm{I})-$ aminoacidate complexes [52,53]. It was established that presence of water in the $\mathrm{H}$-donor solvent up to $4 \%(\mathrm{v} / \mathrm{v})$ was neither beneficial nor detrimental on the reaction rate and selectivity. Based on our experience in aqueous-organic transfer hydrogenation of aldehydes catalyzed by $\left[\left\{\mathrm{RuCl}_{2}(m \text { tppms })_{2}\right\}_{2}\right]+n m$ tppms we initiated a study of transfer hydrogenation of aldehydes from aq. HCOONa in water-2-propanol mixtures. A particularly interesting question was whether both formate and 2-propanol act as H-donors and whether the water/2-propanol ratio effects the selectivity in the case of unsaturated aldehydes. These investigations led to the discovery of an exceedingly fast transfer hydrogenation of aldehydes under mild condition as described in the following.

\section{Experimental}

Aldehydes (Aldrich) and other reagents and solvents were commercially available and used as received. The water-soluble phosphine ligand $m$ tppms [31] and [ $\left.\left\{\mathrm{RuCl}_{2}(m \mathrm{tppms})_{2}\right\}_{2}\right]$ [31] were prepared by published procedures.

All reactions and manipulations were carried out under argon atmosphere. Reaction mixtures were analyzed by gas chromatography (HP5890 Series II; Chrompack WCOT Fused Silica $30 \mathrm{~m} \times 32 \mathrm{~mm}$ CP WAX52CB; FID; carrier gas: argon). The products 
were identified by comparison of their retention times to those of known compounds. ${ }^{1} \mathrm{H},{ }^{31} \mathrm{P}$ and ${ }^{13} \mathrm{C}$ NMR spectra were recorded on a Bruker Avance $360 \mathrm{MHz}$ spectrometer and referenced to 3(trimethylsilyl)propanesulfonic acid Na-salt (DSS).

\subsection{Catalytic hydrogenation of cinnamaldehyde}

In a typical reaction, $408 \mathrm{mg}(6 \mathrm{mmol})$ sodium formate and $126 \mu \mathrm{L}(1 \mathrm{mmol})$ cinnamaldehyde were added to a mixture of $4.0 \mathrm{~mL}$ water and $3.5 \mathrm{~mL}$ 2-propanol at $T=30^{\circ} \mathrm{C} .5 \mathrm{mg}(0.005 \mathrm{mmol})$ $\left[\left\{\mathrm{RuCl}_{2}(\mathrm{mtppms})_{2}\right\}_{2}\right]$ and $16 \mathrm{mg}(0.04 \mathrm{mmol}) \mathrm{mtppms}$ were dissolved in the deoxygenated solution and the mixture was stirred vigorously. Samples $(0.2 \mathrm{~mL})$ were withdrawn periodically and diluted with $1 \mathrm{~mL}$ of water before extraction by chlorobenzene. The organic layers were filtered through short silica plugs and analyzed by gas chromatography.

\section{Results and discussion}

In our earlier studies, we have observed $98 \%$ conversion of cinnamaldehyde with complete selectivity to cinnamyl alcohol by transfer hydrogenation catalyzed by $\left[\left\{\mathrm{RuCl}_{2}(m \mathrm{tppms})_{2}\right\}_{2}\right]+20$ $m$ tppms in an aqueous-organic biphasic system composed of $3 \mathrm{~mL}$ $5 \mathrm{M}$ aqueous HCOONa and $1 \mathrm{mmol}$ of aldehyde (neat) at $80^{\circ} \mathrm{C}$ in $2 \mathrm{~h}$.[45] In the present investigations, it was established that with the same catalyst the reaction hardly proceeded at $30^{\circ} \mathrm{C}$, and only $2.0 \%$ conversion was obtained under the conditions of Table 1. However, in water/organic solvent $2 / 1(\mathrm{v} / \mathrm{v})$ mixtures the transfer hydrogenation became much faster and in case of 2-propanol it led to $90.0 \%$ conversion. Importantly, the only product of the reaction was cinnamyl alcohol (B), and neither $\mathrm{C}$ or $\mathrm{D}$ nor acetals could be detected.

It can be seen from Table 1 that the highest conversion was achieved by using 2-propanol; therefore, we focussed our attention on the use of this solvent. The time course of the reaction is depicted in Fig. 1 and shows that all cinnamaldehyde reacts in $2 \mathrm{~h}$.

Variation of the solvent composition revealed that the conversion changed according to a maximum curve with a plateau between $35 \%$ and $55 \%(v / v)$ concentration of 2-propanol (Fig. 2). In the predominantly aqueous solvents $(\leq 20 \%$ (v/v) 2-propanol), the aldehyde substrate does not dissolve completely, while in the $\geq 80 \%$ $(\mathrm{v} / \mathrm{v})$ 2-propanol range some of the HCOONa remains undissolved. For the rest of investigations, we choose a solvent composition of water/2-propanol 4/3.5 (v/v) (mole fraction of water at this composition is 0.83 ).

The maximum conversions in the range of $35-55 \%(\mathrm{v} / \mathrm{v})$ 2-propanol concentration allow the calculation of a turnover frequency $\mathrm{TOF}=170 \mathrm{~h}^{-1} \quad(\mathrm{TOF}=\mathrm{mol}$ reacted aldehyde $\times(\mathrm{mol}$ catalyst $)^{-1} \times \mathrm{h}^{-1}$ ). At this low reaction temperature, this reflects an exceedingly high reaction rate of the reduction of the aldehyde function. For example, in hydrogenation of cinnamaldehyde with in situ prepared $\mathrm{Ru}(\mathrm{II})-m$ tppts catalyst at $35^{\circ} \mathrm{C}$ and 20 bar $\mathrm{H}_{2}$ pressure, Grosselin et al obtained a TOF of $66 \mathrm{~h}^{-1}$ [13], while Basset et al. have found no reaction in attempted hydrogenation of propi-

Table 1

Effect of organic co-solvent on the transfer hydrogenation of cinnamaldehyde catalyzed by $\left[\left\{\mathrm{RuCl}_{2}(m \mathrm{tppms})_{2}\right\}_{2}\right]+16 m$ tppms.

\begin{tabular}{lc}
\hline Co-solvent & Conversion (\%) \\
\hline None & 2.0 \\
2-Propanol & 90.0 \\
Methanol & 43.1 \\
Ethanol & 48.9 \\
Acetone & 51.0 \\
2-Ethoxyethanol & 39.5 \\
Glycerol & 23.3 \\
\hline
\end{tabular}

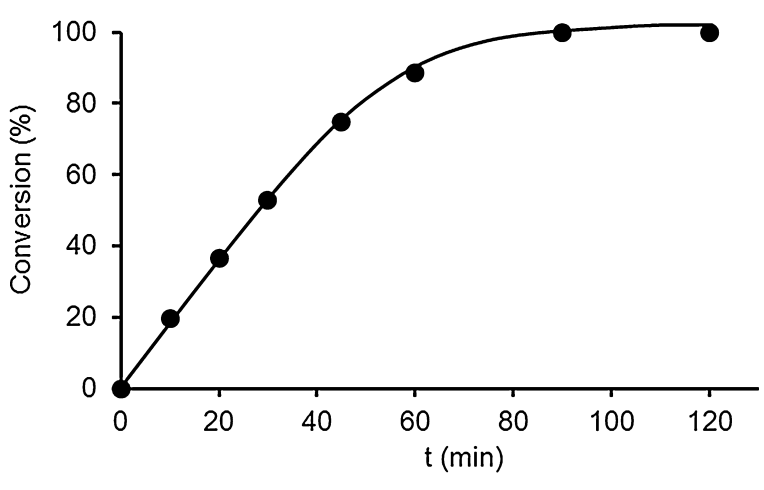

Fig. 1. Time course of the transfer hydrogenation of cinnamaldehyde catalyzed by $\left[\left\{\mathrm{RuCl}_{2}(m \mathrm{tppms})_{2}\right\}_{2}\right]+16 m$ tppms. Conditions: $1 \times 10^{-5} \mathrm{~mol} \mathrm{Ru}, 8 \times 10^{-5} \mathrm{~mol}$ $m$ tppms, $1.0 \mathrm{mmol}$ cinnamaldehyde, $3.0 \mathrm{mmol}$ HCOONa, $5.0 \mathrm{~mL}$ water, $2.5 \mathrm{~mL} 2$ propanol, $T=30^{\circ} \mathrm{C}$.

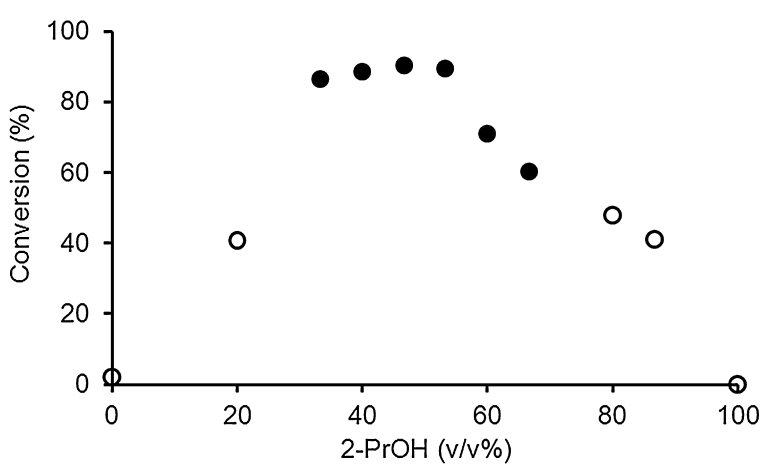

Fig. 2. Effect of solvent composition on the transfer hydrogenation of cinnamaldehyde catalyzed by $\left[\left\{\mathrm{RuCl}_{2}(m \mathrm{tppms})_{2}\right\}_{2}\right]+16 \mathrm{mtppms}$. Conditions: $1 \times 10^{-5} \mathrm{~mol} \mathrm{Ru}$, $8 \times 10^{-5} \mathrm{~mol} \mathrm{mtppms,} 1.0 \mathrm{mmol}$ cinnamaldehyde, $3.0 \mathrm{mmol}$ HCOONa, $V=7.5 \mathrm{~mL}$, $T=30^{\circ} \mathrm{C}, t=1 \mathrm{~h}$.

onaldehyde with several well defined $\mathrm{Ru}(\mathrm{II})-m$ tppts complexes in water at $35^{\circ} \mathrm{C}$ and 50 bar $\mathrm{H}_{2}$ pressure $[25,26]$. In hydrogen transfer from aqueous formate to cinnamaldehyde in the biphasic system studied by us earlier at $80^{\circ} \mathrm{C}$, the highest TOF was $54 \mathrm{~h}^{-1}$ [45]. Therefore, in all respect, the catalytic activities observed in this homogeneous system compare favorably to those found in other systems using similar water-soluble $\mathrm{Ru}(\mathrm{II})$-phosphine catalysts.

In principle, both aqueous HCOONa and 2-propanol can act as $\mathrm{H}$-donors in the transfer hydrogenation of cinnamaldehyde. It is instructive that under conditions of Fig. 2 but replacing HCOONa with $\mathrm{NaHCO}_{3}$ (i.e. with a compound of similar base strength) no reaction occurs. To further learn the role of the two compounds we studied the effect of changing HCOONa/aldehyde ratio on the conversion. In these experiments, $1 \mathrm{mmol}$ cinnamaldehyde was reacted with varying amounts of HCOONa. The results are presented in Table 2.

As shown by the data of Table 2, with substoichiometric amounts of $\mathrm{Na}$-formate the conversion of transfer hydrogenation is limited by the amount of formate present. Nevertheless, upon addition of a new batch of formate the reaction proceeds further (row 3 , data at 120 and $180 \mathrm{~min}$ ) and in the presence of formate excess complete conversion of cinnamaldehyde is obtained. All this evidence points to formate as being the $\mathrm{H}$-donor in this transfer hydrogenation while 2-propanol - at least under these conditions - serves only as part of the solvent mixture. Interestingly, in case of substoichiometric amounts of HCOONa (Table 2, rows 1-3) the yield of cinnamyl alcohol does not reach the amount of added formate. This deviation is caused by the simultaneous decomposition of formate in the aqueous propanol solvent to $\mathrm{H}_{2}$ and $\mathrm{HCO}_{3}{ }^{-}$catalyzed by $\left[\left\{\mathrm{RuCl}_{2}(m \mathrm{tppms})_{2}\right\}_{2}\right]+\mathrm{n} m$ tppms what decreases the amount of 
Table 2

Effect of the formate/aldehyde ratio on the transfer hydrogenation of cinnamaldehyde in aqueous 2-propanol catalyzed by $\left[\left\{\mathrm{RuCl}_{2}(m \mathrm{tppms})_{2}\right\}_{2}\right]+16 \mathrm{mtppms}$.

\begin{tabular}{|c|c|c|c|c|c|}
\hline \multirow[t]{2}{*}{$n_{\mathrm{HCOONa}}(\mathrm{mmol})$} & \multicolumn{5}{|c|}{ Yields of cinnamyl alcohol ( $\mathrm{mmol})$ at various reaction times } \\
\hline & $20 \mathrm{~min}$ & $40 \mathrm{~min}$ & $60 \mathrm{~min}$ & $120 \mathrm{~min}$ & $180 \mathrm{~min}$ \\
\hline 0.3 & 0.22 & 0.23 & 0.23 & 0.23 & \\
\hline 0.6 & 0.44 & 0.48 & 0.49 & & \\
\hline 0.6 & 0.44 & 0.46 & 0.47 & $0.60^{\mathrm{b}}$ & $0.73^{\mathrm{b}}$ \\
\hline $1.0^{\mathrm{a}, \mathrm{c}}$ & 0.10 & 0.24 & 0.29 & & \\
\hline $3.0^{\mathrm{a}}$ & 0.13 & 0.30 & 0.55 & 0.99 & \\
\hline
\end{tabular}

Conditions: $1 \mathrm{mmol}$ cinnamaldehyde, $1 \times 10^{-5} \mathrm{~mol} \mathrm{Ru}, 8 \times 10^{-5} \mathrm{~mol} \mathrm{mtppms}, 5.0 \mathrm{~mL}$ water, $2.5 \mathrm{~mL} 2$-propanol, $t=1 \mathrm{~h}, T=50^{\circ} \mathrm{C}$.

a $T=30^{\circ} \mathrm{C}$.

b After addition a new batch $(0.6 \mathrm{mmol})$ of HCOONa at $60 \mathrm{~min}$.

c 0.99 at $t=17.5 \mathrm{~h}$.

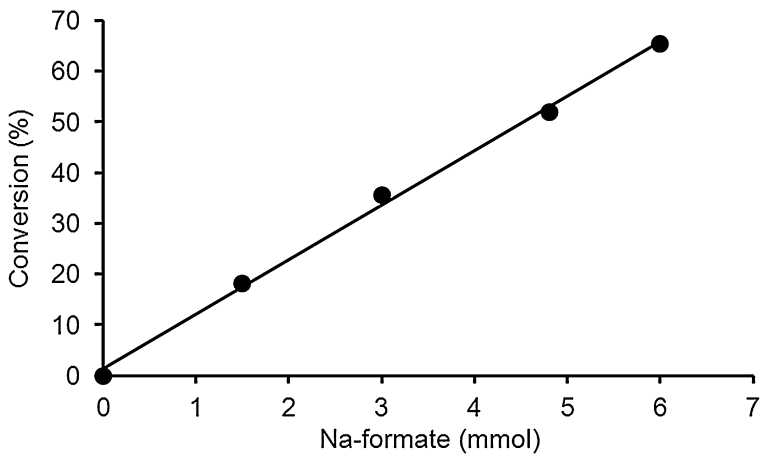

Fig. 3. Transfer hydrogenation of cinnamaldehyde from aqueous $\mathrm{HCOOH} / \mathrm{HCOONa}$ in water-2-propanol mixtures. Conditions: $5.0 \times 10^{-6} \mathrm{~mol} \mathrm{Ru}, 4.0 \times 10^{-5} \mathrm{~mol}$ $m$ tppms, $1.0 \mathrm{mmol}$ cinnamaldehyde, $n_{\mathrm{HCOOH}}+n_{\mathrm{HCOONa}}=6.0 \mathrm{mmol}, 4.0 \mathrm{~mL}$ water, $3.5 \mathrm{~mL}$ 2-propanol, $T=30^{\circ} \mathrm{C}, \mathrm{t}=1 \mathrm{~h}$.

formate available for the transfer hydrogenation reaction. Decomposition of HCOONa by the same catalyst has been observed in purely aqueous solutions, too [54].

The conversion of cinnamaldehyde depends linearly on the concentration of formate (Fig. S1). Interestingly, formic acid is unsuitable as H-donor in this transfer hydrogenation, however there is a smooth reaction in $\mathrm{HCOOH} / \mathrm{HCOONa}$ mixtures, as shown by Fig. 3. It is important to mention that even with $\mathrm{HCOOH} / \mathrm{HCOONa}$ mixtures the sole product of the transfer hydrogenation is cinnamyl alcohol.

The reaction is inhibited by an excess of the substrate therefore the reaction rates go through a maximum with increasing aldehyde concentration (Fig. 4). Note that the highest turnover frequency is close to $160 \mathrm{~h}^{-1}$ showing again the excellent activity of the catalyst at low temperatures. Since under these conditions the

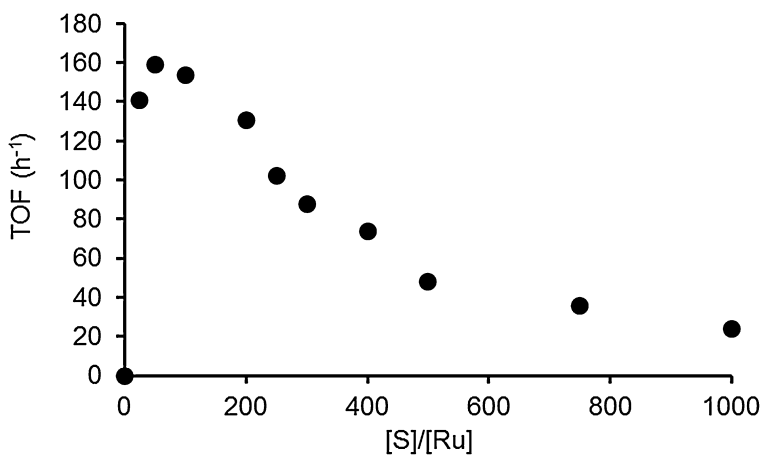

Fig. 4. Transfer hydrogenation of cinnamaldehyde from aqueous HCOONa in water-2-propanol mixtures as a function of the [substrate]/[Ru] ratio. Conditions: $5.0 \times 10^{-6} \mathrm{~mol} \mathrm{Ru}, 4.0 \times 10^{-5} \mathrm{~mol} \mathrm{mtppms}, 6.0 \mathrm{mmol}$ HCOONa, $4.0 \mathrm{~mL}$ water, $3.5 \mathrm{~mL}$ 2-propanol, $T=30^{\circ} \mathrm{C}, t=1 \mathrm{~h}$.

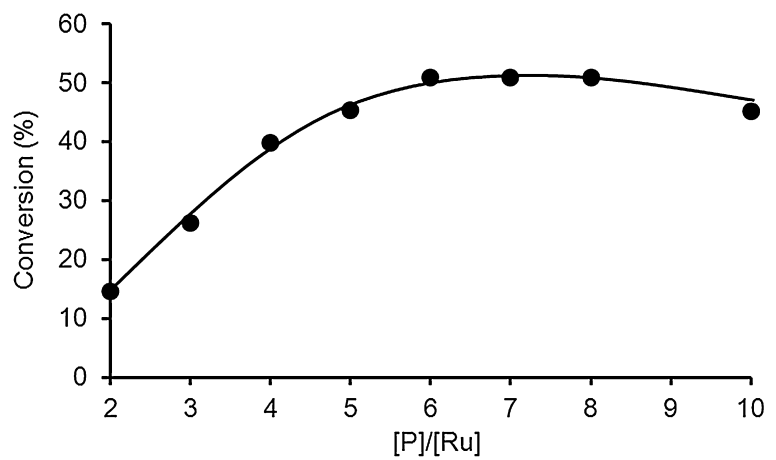

Fig. 5. Transfer hydrogenation of cinnamaldehyde from aqueous HCOONa in water-2-propanol mixtures as a function of the [mtppms]/[Ru] ratio. Conditions: $5.0 \times 10^{-6} \mathrm{~mol} \mathrm{Ru}, 1.0 \mathrm{mmol}$ cinnamaldehyde, $6.0 \mathrm{mmol} \mathrm{HCOONa}, 4.0 \mathrm{~mL}$ water, $3.5 \mathrm{~mL}$ 2-propanol, $T=30^{\circ} \mathrm{C}, t=1 \mathrm{~h}$.

reaction mixtures are homogeneous, substrate inhibition is pronounced already at $[S] /[\mathrm{Ru}]>100$ values.

Similar to the water-chlorobenzene biphasic system [45], conversions of cinnamaldehyde in the homogeneous water-2propanol mixtures also depend on the concentration of added phosphine, i.e. on the $[\mathrm{P}] /[\mathrm{Ru}]$ ratio. This effect is shown in Fig. 5. It is noteworthy that the color of the reaction mixture also changes with the $[\mathrm{P}] /[\mathrm{Ru}]$ ratio. With no added phosphine, the solutions of $\left[\left\{\mathrm{RuCl}_{2}(m \mathrm{tppms})_{2}\right\}_{2}\right]([\mathrm{P}] /[\mathrm{Ru}]=2$ in Fig. 5) turn violet on the action of HCOONa, however, already at $[\mathrm{P}] /[\mathrm{Ru}]=3$ the color of the solution becomes yellow and this color does not change with further increase in the phosphine concentration. The similar rate increase in the water-chlorobenzene biphasic systems was - in part - rationalized by the easier transfer of the substrate to the aqueous catalyst phase facilitated by $m$ tppms known to be an efficient surfactant [45]. However, this can not be the case in the homogeneous water-2-propanol mixtures therefore the beneficial effect of increasing mtppms concentration may be due to its influence on the equilibria of the various $\mathrm{Ru}(\mathrm{II})$-hydride species of different catalytic activity (see later).

The reaction rate shows the expected behavior as a function of temperature (Fig. 6). Transfer hydrogenation takes place - albeit slowly - already at $10^{\circ} \mathrm{C}$, and this is an unexpected feature of this reaction. On the other extreme, at $70^{\circ} \mathrm{C}$ a TOF $=3800 \mathrm{~h}^{-1}$ was determined what is - to the best of our knowledge - the highest obtained so far in transfer hydrogenation of aldehydes from aqueous formate catalyzed by Ru(II)-complexes. An Arrhenius-plot of the ln TOF vs. $1 / T$ yielded an activation energy of $88 \mathrm{~kJ} \mathrm{~mol}^{-1}$. This can be compared to the virtual activation energy (temperature coefficient of

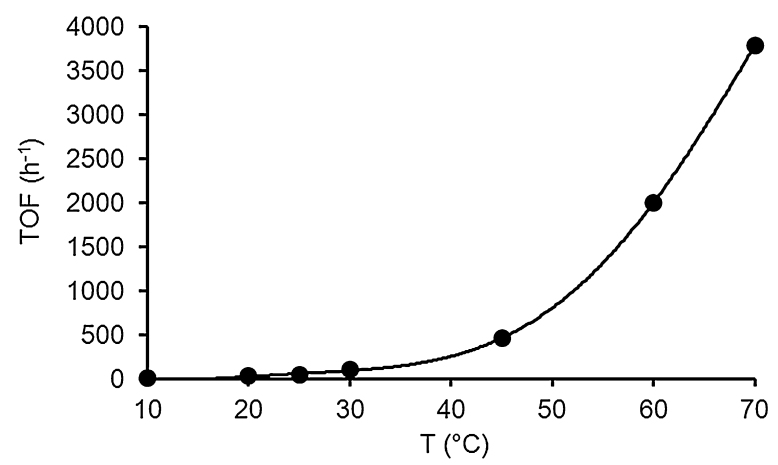

Fig. 6. Transfer hydrogenation of cinnamaldehyde from aqueous HCOONa in water-2-propanol mixtures as a function of the temperature. Conditions: $5.0 \times 10^{-6} \mathrm{~mol} \mathrm{Ru}, 4.0 \times 10^{-5} \mathrm{~mol} m \mathrm{tppms}, 1.0 \mathrm{mmol}$ cinnamaldehyde, $4.0 \mathrm{mmol}$ HCOONa, $4.0 \mathrm{~mL}$ water, $3.5 \mathrm{~mL} 2$-propanol, $t=1 \mathrm{~h}$. 
Table 3

Transfer hydrogenation of various aldehydes in water-2-propanol mixtures catalyzed by $\left[\left\{\mathrm{RuCl}_{2}(m \mathrm{tppms})_{2}\right\}_{2}\right]+16 \mathrm{mtppms}$.

\begin{tabular}{lll}
\hline Aldehyde & \multicolumn{2}{l}{ Conversion (\%) } \\
\cline { 2 - 3 } \cline { 2 - 3 } & $t=0.5 \mathrm{~h}$ & $t=1 \mathrm{~h}$ \\
\hline Cinnamaldehyde & 33.2 & 65.4 \\
3-Phenylpropionaldehyde & 43.6 & 79.2 \\
Benzaldehyde & 36.2 & 81.9 \\
Citronellal & 36.7 & 80.8 \\
4-Bromobenzaldehyde & 99.7 & 99.9 \\
4-Ethoxybenzaldehyde & 99.6 & 99.7 \\
Citral & 31.8 & 64.8 \\
Cyclohexanecarboxaldehyde & 40.1 & 60.8 \\
2-Fluorobenzaldehyde & n.d. & 39.4 \\
3-Fluorobenzaldehyde & n.d. & 24.1 \\
4-Fluorobenzaldehyde & n.d. & 47.8 \\
4-Trifluoromethylbenzaldehyde & n.d. & 40.0 \\
3-Methylbenzaldehyde & n.d. & 18.9 \\
Pyridine-3-carboxaldehyde & 0 & 0 \\
2-Aminobenzaldehyde & 0 & 0 \\
\hline
\end{tabular}

Conditions: $5.0 \times 10^{-6} \mathrm{~mol} \mathrm{Ru}, 1.0 \mathrm{mmol}$ cinnamaldehyde, $6.0 \mathrm{mmol} \mathrm{HCOONa}, 4.0 \mathrm{~mL}$ water, $3.5 \mathrm{~mL} 2$-propanol, $T=30^{\circ} \mathrm{C}$; n.d., not determined.

the reaction rate) of the transfer hydrogenation of benzaldehyde, $98 \mathrm{~kJ} \mathrm{~mol}^{-1}$, determined for the water-chlorobenzene biphasic reaction [45] (no such data are available for cinnamaldehyde). However, this latter is a composite value including contributions from the temperature dependence of solubilities (partition coefficients) of benzaldehyde and all other components (benzyl alcohol, solvents) of the reaction system.

The scope of the reaction was investigated at $30^{\circ} \mathrm{C}$ and the results are collected in Table 3. Pyridine-3-carboxaldehyde and 2-aminobenzaldehyde were completely unreactive, probably due to $\mathrm{N}$-coordination or to the presence of strong internal $\mathrm{H}$-bond, respectively. The rest of the investigated substrates, however, could be reduced to the corresponding alcohols with good to excellent reaction rates. Transfer hydrogenation of citral yielded geraniol and nerol in 2:1 ratio, i.e. no cis-trans isomerization took place during reduction of the carbonyl group. Products of the transfer hydrogenation can be obtained by extraction of a suitable solvent (e.g. diethyl ether or hexane) after dilution of the reaction mixture with water.

The main new feature of the catalytic reduction of aldehydes in water-2-propanol mixed solvents is in their unexpectedly high reaction rate. Several effects should be taken into consideration for finding an explanation of this phenomenon. In principle, a significant contribution may arise from the homogeneity of the reaction mixtures. As mentioned in connection with Fig. 2, below $20 \%(\mathrm{v} / \mathrm{v})$ 2-propanol concentration the aldehyde substrate does not dissolve completely, while in the $\geq 80 \%(\mathrm{v} / \mathrm{v}) 2$-propanol range some of the HCOONa remains undissolved. Table 1 shows results of experiments when $1 \mathrm{mmol}$ of cinnamaldehyde was added either to $7.5 \mathrm{~mL}$ water or to a homogeneous mixture of $5 \mathrm{~mL}$ water and $2.5 \mathrm{~mL} 2$ propanol. In the former case, a biphasic system is obtained in which the concentration of cinnamaldehyde in the catalyst-containing aqueous phase is limited by its solubility: $10.8 \mathrm{mM}$ (at $25^{\circ} \mathrm{C}$ ) [55]. In contrast, the water-2-propanol mixture dissolves all the $1 \mathrm{mmol}$ cinnamaldehyde giving a homogeneous solution, and this results in a $13.3 \mathrm{mM}$ substrate concentration. Obviously, the small increase of the concentration of dissolved cinnamaldehyde upon addition of 2-propanol cannot explain the jump of the conversion from $2.0 \%$ (no cosolvent) to $90.0 \%$ (33\%, v/v, 2-propanol). Furthermore, increasing the $[S] /[C]$ ratio above 40 results in substrate inhibition (Fig. 4) and this again does not support the assumption that the large rate increase is simply caused by the higher concentration of cinnamaldehyde in the water-2-propanol solvent mixture.

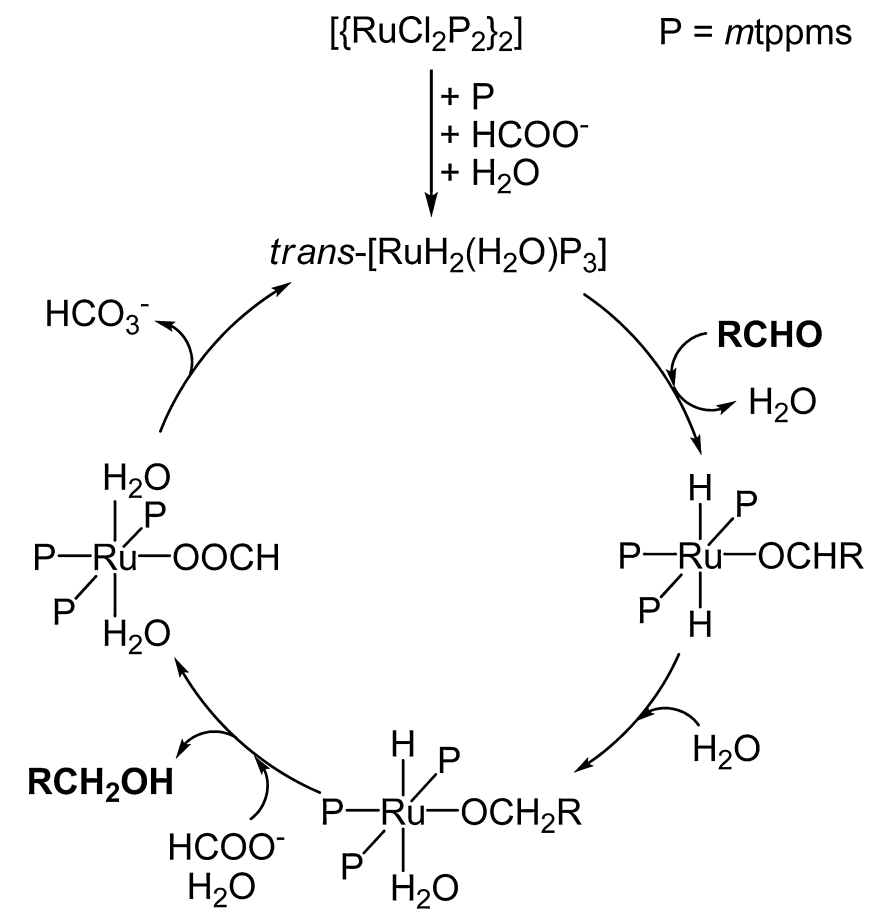

Scheme 2. Suggested mechanism of the transfer hydrogenation of cinnamaldehyde with $\mathrm{HCOONa} / \mathrm{H}_{2} \mathrm{O}$ catalyzed by $\left[\left\{\mathrm{RuCl}_{2}(m \mathrm{tppms})_{2}\right\}_{2}\right]+n m$ tppms.

2-Propanol can also affect the reaction mechanism by influencing the formation and further transformation of catalytically important intermediates. Earlier, we have determined by multinuclear NMR spectroscopy that in aqueous formate solutions of $\left[\left\{\mathrm{RuCl}_{2}(m \mathrm{tppms})_{2}\right\}_{2}\right]+n m$ tppms the two dominant $\mathrm{Ru}(\mathrm{II})$ species were trans-[ $\left.\mathrm{RuH}_{2}(\mathrm{HCOO})(m \mathrm{tppms})_{3}\right]^{-}$ $\left(\delta_{\mathrm{H}}=-19.2 \mathrm{ppm}, \delta_{\mathrm{P}(\mathrm{A})}=44.0 \mathrm{ppm}(\mathrm{s})\right.$ and $\left.\delta_{\mathrm{P}(\mathrm{B})}=79.2 \mathrm{ppm}(\mathrm{t})\right)$ and trans- $\left[\mathrm{RuH}_{2}\left(\mathrm{H}_{2} \mathrm{O}\right)(m \mathrm{tppms})_{3}\right]\left(\delta_{\mathrm{H}}=-17.7 \mathrm{ppm}, \delta_{\mathrm{P}(\mathrm{A})}=44.0 \mathrm{ppm}(\mathrm{s})\right.$ and $\left.\delta_{\mathrm{P}(\mathrm{B})}=77.1 \mathrm{ppm}(\mathrm{t})\right)[50]$. Selective ${ }^{31} \mathrm{P}$ decoupling unambiguously showed the trans-mer coordination in the ' $\mathrm{RuH}_{2}(m \mathrm{tppms})_{3}{ }^{\prime}$ fragment of octahedral complexes. These solutions have a strong yellow color characteristic also for the catalytic reaction mixtures and the composition of the observed species is in accord with the higher activity of the catalysts with $[P] /[R u] \geq 3$. The same NMR spectra could be recorded for solutions of $\left[\left\{\mathrm{RuCl}_{2}(m \mathrm{tppms})_{2}\right\}_{2}\right]+n$ $m$ tppms + HCOONa in water/2-propanol $1 / 1(\mathrm{v} / \mathrm{v})$ mixtures, too (Figs. S2 and S3). Based upon these observations a simplified reaction mechanism is suggested (Scheme 2 ) with the assumption that trans-[ $\left.\mathrm{RuH}_{2}\left(\mathrm{H}_{2} \mathrm{O}\right)(\mathrm{mtppms})_{3}\right]$ is the catalytically active species.

The $\mathrm{H}_{2} \mathrm{O}$ ligand in trans- $\left[\mathrm{RuH}_{2}\left(\mathrm{H}_{2} \mathrm{O}\right)(m \text { tppms })_{3}\right]$ is expected to be readily replaced by the aldehyde substrate. Internal hydride migration to the coordinated aldehyde and protonation of the resulting alkoxide complex by water would release the alcohol product while coordination of formate and its decomposition to $\mathrm{CO}_{2}$ (bicarbonate) within the coordination sphere of $\mathrm{Ru}(\mathrm{II})$ would give back the trans-[ $\left.\mathrm{RuH}_{2}\left(\mathrm{H}_{2} \mathrm{O}\right)(m \text { tppms })_{3}\right]$ catalyst. Similar suggestions were already made concerning the mechanism of aldehyde hydrogenation $[25,26]$. However, several fine details of the mechanism (coordination mode of the aldehyde, the precise steps of formation of $\mathrm{Ru}$ (II)-hydrides on the action of formate in aqueous solutions, etc.) still remain elusive. In purely aqueous solutions, release of the hydrophobic alcohol product may be a slow step in the cycle and we assume that this is the point where an organic cosolvent may exert a positive effect (Table 1) on the overall reaction rate.

In summary, we have developed a fast and efficient method for transfer hydrogenation of aldehydes in aqueous 2-propanol with 
$\left[\left\{\mathrm{RuCl}_{2}(m \text { tppms })_{2}\right\}_{2}\right]+n m$ tppms catalyst and Na-formate as $\mathrm{H}$ donor. Execution and workup of the reaction is simple and the products can be obtained in high purity. The low reaction temperature makes possible the reduction of heat sensitive or highly volatile substances, too. A particular advantage of the reaction is the complete selectivity in transfer hydrogenation of unsaturated aldehydes to unsaturated alcohols.

\section{Acknowledgements}

The research was supported by the EU and co-financed by the European Social Fund under the project ENVIKUT (TÁMOP-4.2.2.A11/1/KONV-2012-0043). Thanks are due to the Hungarian Research Fund (OTKA K101372) for financial support. G.P. is grateful for a János Bolyai Research Scholarship of the Hungarian Academy of Sciences.

\section{References}

[1] B. Cornils, W.A. Herrmann (Eds.), Applied Homogeneous Catalysis with Organometallic Compounds, VCH, Weinheim, 1996.

[2] F. Joó, Á. Kathó, J. Mol. Catal. A: Chem. 116 (1997) 3-26.

[3] F. Joó, Biphasis catalysis (homogeneous), in: I.T. Horváth (Ed.-in-chief), Encyclopedia of Catalysis, 2nd revised ed., Wiley, New York, Published online 15 Sept 2010, DOI: 10.1002/0471227617 http://onlinelibrary. wiley.com/book/10.1002/0471227617.

[4] F. Joó, Á. Kathó, Two-phase aqueous hydrogenations, in: J.G. de Vries, C.J. Elsevier (Eds.), Handbook of Homogeneous Hydrogenation, Wiley-VCH, Weinheim, 2007, pp. 1327-1359.

[5] F. Joó, Á. Kathó, Water as green solvent for bulk chemicals, in: C.-J. Li (Ed.), Reactions in Water (Handbook of Green Chemistry, vol. 5. Green Solvents), Wiley-VCH, Weinheim, 2010, pp. 389-408.

[6] F. Joó, Aqueous Organometallic Catalysis, Kluwer, Dordrecht, 2001

[7] F. Joó, Acc. Chem. Res. 35 (2002) 738-745.

[8] J.S.M. Samec, J.-E. Bäckvall, P.G. Andersson, P. Brandt, Chem. Soc. Rev. 35 (2006) $237-248$

[9] X. Wu, J. Liu, X. Li, A. Zanotti-Gerosa, F. Hancock, D. Vinci, J. Ruan, J. Xiao, Angew. Chem. Int. Ed. 45 (2006) 6718-6722.

[10] J. Li, Y. Zhang, D. Han, G. Jia, J. Gao, L. Zhong, C. Li, Green Chem. 10 (2008) 608-611.

[11] A.N. Ajjou, J.-L. Pinet, J. Mol. Catal. A: Chem. 214 (2004) 203-206.

[12] L.G. Melean, M. Rodriguez, A. Gonzalez, B. Gonzalez, M. Rosales, P.J. Baricelli, Catal. Lett. 141 (2011) 709-716.

[13] J.M. Grosselin, C. Mercier, G. Allmang, F. Grass, Organometallics 10 (1991) $2126-2133$.

[14] J.M. Grosselin, C. Mercier, J. Mol. Catal. 63 (1990) L25-L27.

[15] J.M. Grosselin, C. Mercier, USP 4,925,990 to Rhone-Poulenc Sante, 1990.

[16] C. Mercier. P. Chabardes, Pure Appl. Chem. 7 (1994) 1509-1518.

[17] K. Nuithitikul, M. Winterbottom, Chem. Eng. Sci. 59 (2004) 5439-5447.

[18] K. Nuithitikul, M. Winterbottom, Catal. Today 128 (2007) 74-79.

[19] M. Marchetti, F. Minello, S. Paganelli, O. Piccolo, Appl. Catal. A: Gen. 373 (2010) $76-80$.
[20] S.F. Dio, M. Marchetti, S. Paganelli, O. Piccolo, Appl. Catal. A: Gen. 399 (2011) 205-210.

[21] L. Lavenot, A. Roucoux, H. Patin, J. Mol. Catal. A: Chem. 118 (1997) 153-159

[22] H. Gulyás, A.C. Bényei, J. Bakos, Inorg. Chim. Acta 357 (2004) 3094-3098.

[23] (a) F. Joó, J. Kovács, A.C. Bényei, Á. Kathó, Angew. Chem 110 (1998) 1024-1026; (b) F. Joó, J. Kovács, A.C. Bényei, Á. Kathó, Angew. Chem. Int. Ed. Engl 37 (1998) 969-970.

[24] F. Joó, J. Kovács, A.C. Bényei, Á. Kathó, Catal. Today 42 (1998) 441-448.

[25] E. Fache, F. Senocq, C. Santini, J.-M. Basset, J. Chem. Soc., Chem. Commun. (1990) $1776-1778$.

[26] E. Fache, F. Senocq, C. Santini, J.M. Basset, J. Mol. Catal. 72 (1992) 337-350.

[27] G. Papp, J. Kovács, A.C. Bényei, G. Laurenczy, L. Nádasdi, F. Joó, Can. J. Chem. 79 (2001) 635-641.

[28] G. Papp, J. Elek, L. Nádasdi, G. Laurenczy, F. Joó, Adv. Synth. Catal. 345 (2003) $172-174$.

[29] R.A. Sánchez-Delgado, M. Medina, F. López-Linares, A. Fuentes, J. Mol. Catal. A: Chem. 116 (1997) 167-177.

[30] M. Hernandez, P. Kalck, J. Mol. Catal. A: Chem. 116 (1997) 131-146.

[31] F. Joó, J. Kovács, Á. Kathó, A.C. Bényei, T. Decuir, D.J. Darensbourg, Inorg. Synth. 32 (1998) $1-8$.

[32] W.A. Herrmann, C.W. Kohlpaintner, Inorg. Synth. 32 (1998) 8-25.

[33] D.J. Daigle, Inorg. Synth. 32 (1998) 40-45.

[34] P. Csabai, F. Joó, Organometallics 23 (2004) 5640-5643.

[35] V. Cadierno, P. Crochet, J. Francos, S.E. García-Garrido, J. Gimeno, N. Nebra, Green Chem. 11 (2009) 1992-2000.

[36] V. Cadierno, J. Francos, J. Gimeno, N. Nebra, Chem. Commun. (2007) 2536-2538

[37] S. Hashiguchi, A. Fujii, J. Takehara, T. Ikariya, R. Noyori, J. Am. Chem. Soc. 117 (1995) 7562-7563

[38] X. Wu, X. Li, A. Zanotti-Gerosa, A. Pettman, J. Liu, A.J. Mills, J. Xiao, Chem. Eur. J. 14 (2008) 2209-2222.

[39] T. Thorpe, J. Blacker, S.M. Brown, C. Bubert, J. Crosby, S. Fitzjohn, J.P. Muxworthy, J.M.J. Williams, Tetrahedron Lett. 42 (2001) 4041-4043.

[40] C. Bubert, J. Blacker, S.M. Brown, J. Crosby, S. Fitzjohn, J.P. Muxworthy, T. Thorpe J.M.J. Williams, Tetrahedron Lett. 42 (2001) 4037-4039.

[41] X. Wu, X. Li, W. Hems, F. King, J. Xiao, Org. Biomol. Chem. 2 (2004) 1818-1821.

[42] R. Bar, Y. Sasson, J. Blum, J. Mol. Catal. 26 (1984) 327-332.

[43] R. Bar, L.K. Bar, Y. Sasson, J. Blum, J. Mol. Catal. 33 (1985) 161-177.

[44] F. Joó, A. Bényei, J. Organomet. Chem. 363 (1989) C19-C21.

[45] A. Bényei, F. Joó, J. Mol. Catal. 58 (1990) 151-163.

[46] D.J. Darensbourg, F.Joó, M. Kannisto, Á. Kathó, J.H. Reibenspies, Organometallics 11 (1992) 1990-1993.

[47] D.J. Darensbourg, F. Joó, M. Kannisto, Á. Kathó, J.H. Reibenspies, D.J. Daigle, Inorg. Chem. 33 (1994) 200-208.

[48] S. Ogo, N. Makihara, Y. Watanabe, Organometallics 18 (1999) 5470-5474.

[49] T. Abura, S. Ogo, Y. Watanabe, S. Fukuzumi, J. Am. Chem. Soc. 125 (2003) 4149-4154.

[50] G. Papp, H. Horváth, G. Laurenczy, I. Szatmári, Á. Kathó, F. Joó, Dalton Trans. 42 (2013) 521-529.

[51] S. Tilloy, H. Bricout, E. Monflier, Green Chem. 4 (2002) 188-193.

[52] D. Carmona, F.J. Lahoz, R. Atencio, L.A. Oro, M. Pilar Lamata, F. Viguri, E. San José, C. Vega, J. Reyes, F. Joó, Á. Kathó, Chem. Eur. J. 5 (1999) 1544-1564.

[53] Á. Kathó, D. Carmona, F. Viguri, C.D. Remacha, J. Kovács, F. Joó, L.A. Oro, J. Organomet. Chem. 593-594 (2000) 299-306.

[54] G. Papp, J. Csorba, G. Laurenczy, F. Joó, Angew. Chem. Int. Ed. 50 (2011) 10433-10435.

[55] S.C. Valvani, S.H. Yalkowsky, T.J. Roseman, J. Pharm. Sci. 70 (1981) 502-507. 